\author{
V.V. Kalinchak, O.S. Chernenko A.V. Fedorenko
}

\title{
Electric Resistence Hysteresis of Platinum Filament in Cold Air/Hydrogen Mixtures
}

\author{
Odessa I.I. Mechnykov National University, Odessa, Ukraine, teplophys@onu.edu.ua
}

\begin{abstract}
Ignition of gaseous combustible mixtures on catalytically active hot solid surfaces has numerous applications in many industrial processes and is a complex process that involves close interaction between surface processes and transfer processes in the gas mixture. In this paper, stable and critical states catalytic oxidation of hydrogen impurities in air on a platinum filament are considered. It is shown that filament temperature and its resistance depending on the mixture temperature and hydrogen concentration are of the hysteresis features. Within this hysteresis region, it is possible to achieve the catalytic combustion mode of hydrogen as a result preheating the catalyst filament above a certain critical value. The dependence of the limiting hydrogen's concentration on catalyst filament's diameter, above which is observed in the cold gas mixture self-sustaining catalytic combustion without electric current.
\end{abstract}

Key words: hysteresis, platinum wire, catalyst, forced ignition, self-sustaining combustion, cold hydrogenair mixture.

Received 19 August 2020; Accepted 15 September 2020.

\section{Introduction}

The use of wire meshes, which is coated with a thin layer of platinum or metal oxide [1-3], has an advantage over powder catalysts primarily due to the ease of removing them from the reaction zone and the need for filtration. They are convenient to use in the heterogeneous catalysis's oxidation reactions of various gaseous substances. In this case, to intensify the catalytic process, the mesh is heated.

To study the heterogeneous oxidation of combustible gas on a single catalyst wire, it is heated by electric current [4-5]. With the correct catalyst choice, the catalytic ignition of the combustible gas impurity is possible when the heating current force or the gas mixture's temperature increases to values exceeding the critical values.

Thin metallic catalyst filament is normally applied as an initial sensor of thermochemical gas detector indicating presence of combustible gases in air/gas mixtures. Its operation is based on application of upper high-temperature regime of hysteretic (binary) relation between catalyst metallic filament temperature and combustible gas admixture concentration in air gas mixture with steady heating by electric current and air/gas flow temperature [6]. The upper steady mode is described by linear relation of flameless combustion temperature and combustible gas admixture content for thin filament, where heat losses with radiation may be ignored [7]. It is also possible to use the linear dependence of the flameless combustion temperature on the heating current's square or the gas stream's temperature at a constant impurity concentration $[8,9]$.

Works [7-9] are focused on hysteretic nature of relation between filament temperature and system's ambient parameters. It is caused by non-linear relation chemical heat emission intensity and temperature. Studies of thermal hysteresis parameters allowing to identify chemical reactions' parameters is an important aspect of heterogeneous catalysis [10]. Another wellknown example is temperature hysteresis in the catalytic oxidation of carbon monoxide and propane [11].

In [7] it was experimentally shown that if the combustible gas impurity concentration is higher than some critical value, then after switching off the electric current the catalytic combustion of hydrogen or ammonia in a cold gas mixture on a thin platinum wire becomes 
self-supporting. In [12], the limit values of hydrogen impurity concentration and catalyst temperature are analytically found, above which the catalytic flameless self-supporting stable combustion of gas-air mixtures of room temperature on platinum wire is observed.

Admixture content may establish linear relation with metallic catalyst filament resistance or potentials drop at the ends of the wire filament. It is possible with minor thermal losses with radiation, combustible gas first order catalyst reaction and its running in diffusion mode.

Specific feature of hysteretic relation between filament temperature and, for example, gaseous mixture temperature [9] consists in possible gas catalytic combustion in cold mixtures due to catalyst preheating. Such a process is known as compelled gas ignition, which is so far insufficiently studied.

Aim of work consists in analytic description of relation between electric resistance of metallic filament and combustible gas concentration and air/gas mixture temperature. Subject of research consists in modes of catalyst oxidation of hydrogen in air/hydrogen mixture (volumetric content below 10\%) on thin platinum filament $(d=0.1 \mathrm{~mm}, \quad L=108 \mathrm{~mm})$ $\left(\mathrm{H}_{2}+0.5 \mathrm{O}_{2} \stackrel{p_{t}}{\longrightarrow} \mathrm{H}_{2} \mathrm{O}\right)$ introduced into electric circuit with stabilized intensity of electric current.

\section{Forced catalytic ignition}

Time dependence of temperature on metallic catalyst resistance is defined from hysteretic non-stationery heat balance equation [8]:

$$
\begin{gathered}
c_{c} \rho_{c} \frac{d}{4} \frac{\partial T}{\partial \tau}=q_{e f f}, q_{e f f}=q_{c h}+q_{j}-q_{g} T(t=0)=T_{b}, \\
q_{c h}=Q_{a} \rho_{g s} k Y_{a, s}\left(1+\psi_{T}\right), q_{j}=\frac{4 I^{2} \eta}{\pi^{2} d^{3}}, \\
q_{g}=\beta c_{p, g} \rho_{g} L e^{-1+m}\left(T-T_{g 0}\right), \quad Y_{a s}=\frac{Y_{a}}{1+S e}, \\
\psi_{T}=k_{T} \frac{T-T_{g}}{T}=(2-n) \frac{T-T_{g}}{T} L e^{m}[7], \\
\text { Se }=\frac{k \rho_{g s}}{\beta \rho_{g}}, \beta=\frac{D_{a} S h}{d}, k_{a}=D_{a 0}\left(\frac{T+T_{g 0}}{2 T_{0}}\right)^{n}, \\
\rho_{g s}=\rho_{g 0} \frac{T_{0}}{T}, \rho_{g}=\rho_{g 0} \frac{2 T_{0}}{T+T_{g 0}},
\end{gathered}
$$

with $q_{c h}$ - specific rate of chemical heat release, $\mathrm{W} / \mathrm{m}^{2}$; $\mathrm{q}_{\mathrm{j}}$ - specific power of Joule heat release, $\mathrm{W} / \mathrm{m}^{2} ; \mathrm{q}_{\mathrm{g}}$ is the heat flux density in the gas mixture, $\mathrm{W} / \mathrm{m}^{2} ; Q_{a}-$ reaction heat effect, $\mathrm{J} / \mathrm{kg} ; T_{g 0}$ - air/gas mixture temperature, $\mathrm{K}$; $Y_{a s}, Y_{a}-$ combustible gas relative mass ratio near filament surface and in air/gas mixture, $S e$ - diffusion/kinetic relation (relation between diffusion and kinetic resistance), $E$ - activation energy, J/mole; $R$ - absolute gas constant, $\mathrm{J} /($ mole $\cdot \mathrm{K}) ; \psi_{T}-$ thermal diffusion correction, $L$ - catalyst filament length, $\eta$ - filament specific resistance; $L e=D_{a} / a_{g}$-the Lewis number.
The increase in the time derivative temperature of the catalyst filament is due to the thermal effect of the chemical reaction and electric current in a conductor with non-zero resistance, and the decrease is determined by the rate of heat loss by heat exchange with cold gas air flow. Radiant heat loss can be neglected.

As done in [7, 9], to consider critical and stable stationary regimes, we introduce an effective ambient temperature. This is the temperature of the inert wire heated by the Joule heat:

$T_{g}=T_{g 0}+\frac{q_{j}}{\beta c_{p g} \rho_{g} L e^{-1+m}}=T_{g 0}+\frac{4 \eta L e^{1-m}}{S h \pi^{2} D_{a} c_{p g} \rho_{g}}\left(\frac{I}{d}\right)^{2}$.

Using (2), from the condition of stationary temperature (1) we express the gas temperature as a function of the stationary catalyst temperature at a constant combustible gas's concentration in the air:

$$
\begin{gathered}
T_{g}=T-\frac{T_{Q} Y_{a}}{\left(\frac{1+S e}{S e}-(2-n) \frac{T_{Q} Y_{a}}{T} L e^{m}\right)}, \\
T_{Q}=\frac{Q_{a} L e^{1-m}}{c_{p g}},
\end{gathered}
$$

Here, the second term in the denominator determines the role of thermal diffusion of the light combustible component.

The resistance of the platinum thread $r_{e l}$ is determined by the linear dependence of its temperature:

$$
r_{e l}=r_{e l, 0}\left[1+\Omega\left(T-T_{0}\right)\right]=\frac{4 L \eta_{0}}{\pi d^{2}}\left[1+\Omega\left(T-T_{0}\right)\right],
$$

where $L$ is catalyst filament length, $\eta$ is the filament resistivity.

Calculations have been performed applying parameters, as follows, $E=55 \mathrm{~kJ} / \mathrm{mole}, k_{0}=0.8 \cdot 10^{6}$ $\mathrm{m} / \mathrm{s}, Q_{a}=120.9 \mathrm{MJ} / \mathrm{kgH}_{2}, D_{a 0}=0.6 \cdot 10^{-4} \mathrm{~m}^{2} / \mathrm{s}, m=0.33$, $n=1.82, S h=0.51(U=0.15 \mathrm{~m} / \mathrm{s}), T_{0}=273 \mathrm{~K}, \rho_{g 0}=$ $1.293 \mathrm{~kg} / \mathrm{m}^{3}, c_{g}=1005 \mathrm{~J} /(\mathrm{kg} \cdot \mathrm{K}), \Omega=39.3 \cdot 10^{-4} \mathrm{~K}^{-1}, \eta_{0}=$ $9.81 \cdot 10^{-8} \mathrm{Ohm} \cdot \mathrm{m}$.

Fig. 1a represents a parametrical relation (2), (4) between air/gas mixture efficient temperature and platinum filament relative resistance for two values of hydrogen admixture concentration with $r_{e l} / r_{e l, 0} \approx T / T_{0}$.

Obviously, two ways differing in quality may enable to achieve an air/gas mixture catalytic combustion mode on catalyst filament:

1. Gaseous mixture efficient temperature may be increased either by means of direct heating, or by means of electric current to exceed critical ignition point $T_{g}>T_{g i}$. In this case the catalyst filament temperature increases spontaneously. At an ignition temperature $T_{g i}$. Chemical reaction takes place in kinetic zone $S e \ll 1[7,9]$. Under such a condition the $T_{g i}$ value slightly depends on the filament diameter [6]. Therefore, as illustrated by (3) the current intensity value for catalytic ignition takes a linear dependence on filament diameter as it is heated by electric current

2. Catalyst filament direct preheating with initial filament temperature exceeding ignition point - a certain critical value (Fig. 2). IT is possible providing the 
gaseous mixture falls within an interval $T_{g e}<T_{g}<T_{g i}$. Critical values of initial temperature of catalyst filament (point i) are within self-ignition point (condition point i) and extinction point (point e) (Fig. 1a, extended dash line) and obey the equation (3).

Catalytic combustion ceases with catalytic combustion temperature decrease to fade point (Fig. 1a, condition point e, curve 1) or as a result of gaseous mixture temperature drop $\left(T_{g}<T_{g e}\right)$, or combustible gas ratio drop (Fig. 1b). Steady catalytic combustion may be maintained at high combustible gas ratio even with mixture temperature drop to indoor temperature value which may be considered identical to switching off the electric current supplied to the filament (Fig. 1a, curve 2).

The dependence of combustible gas's concentration on the catalyst's stationary temperature is determined from the condition of stationary temperature (1) and is presented in the form:

$$
Y_{a}=\frac{S h}{d} \frac{D_{a} \rho_{g}}{\left(1+\psi_{T}\right) \rho_{g s} k_{0}}(1+S e) \frac{\left(T-T_{g}\right)}{T_{Q}} \exp \left(\frac{E}{R T}\right) .
$$

Fig. 1b illustrates that admixture critical ratio $Y_{a i}$ provoking catalytic self-ignition of gaseous admixture depends on efficient temperature value of gaseous mixture. For instance, its increase to $20 \mathrm{~K}$ only results to double decrease of admixture ratio required for selfignition. Therefore, only catalytic ignition is applicable for wide range of efficient temperature of gaseous mixtures.

Fig. 1 illustrates that the filament resistance (and, consequently, temperature) in catalytic combustion mode experiences a linear magnification with increase of hydrogen admixture ratio and air gas mixture efficient temperature.
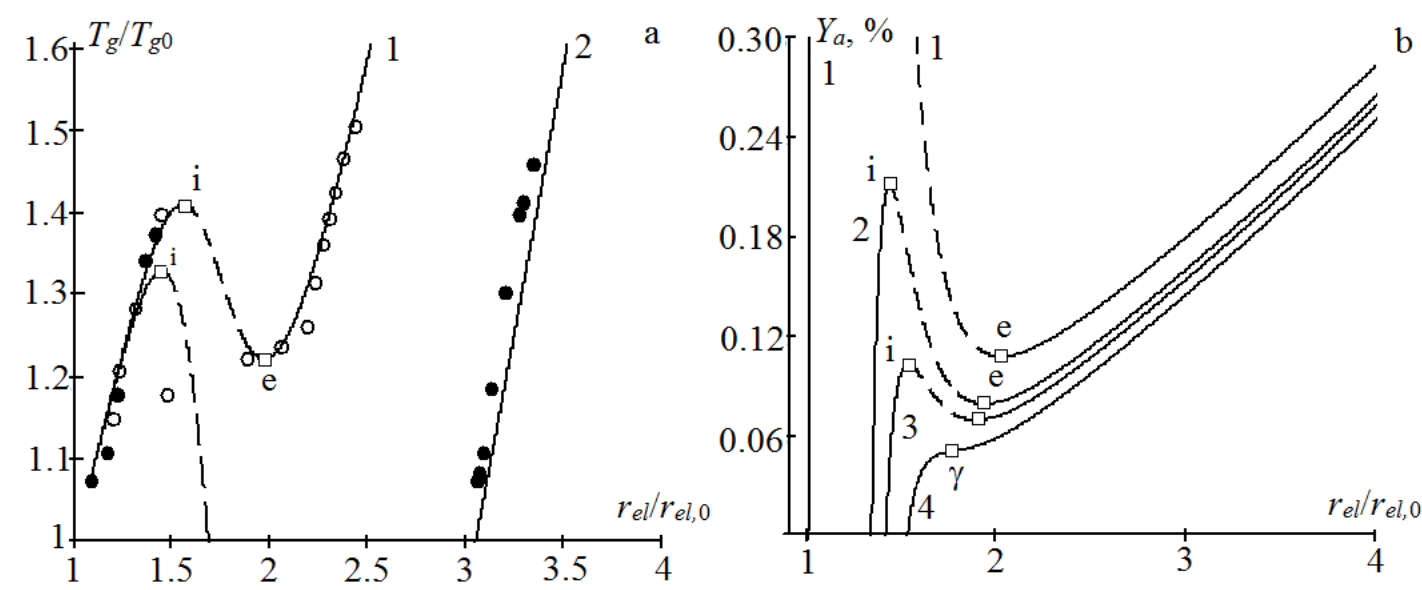

Fig. 1a. Relation of abstract air/hydrogen mixture temperature and platinum filament stationery resistance. Hydrogen ratio $Y_{a}:$ 1) $0.09 \%$, 2) $0.19 \%$. Filament diameter $100 \mu \mathrm{m}, \mathrm{Sh}=0.51$.

Calculations completed applying (3) and (4).

Fig. 1b. Hydrogen admixture ratio dependence on catalyst wire stationery resistance. Air/gas mixture temperature $T_{g}:$ 1) $293 \mathrm{~K}$, 2) $\left.\left.360 \mathrm{~K}, 3\right) 380 \mathrm{~K}, 4\right) 410 \mathrm{~K}$. Calculations completed applying (4) and (5).
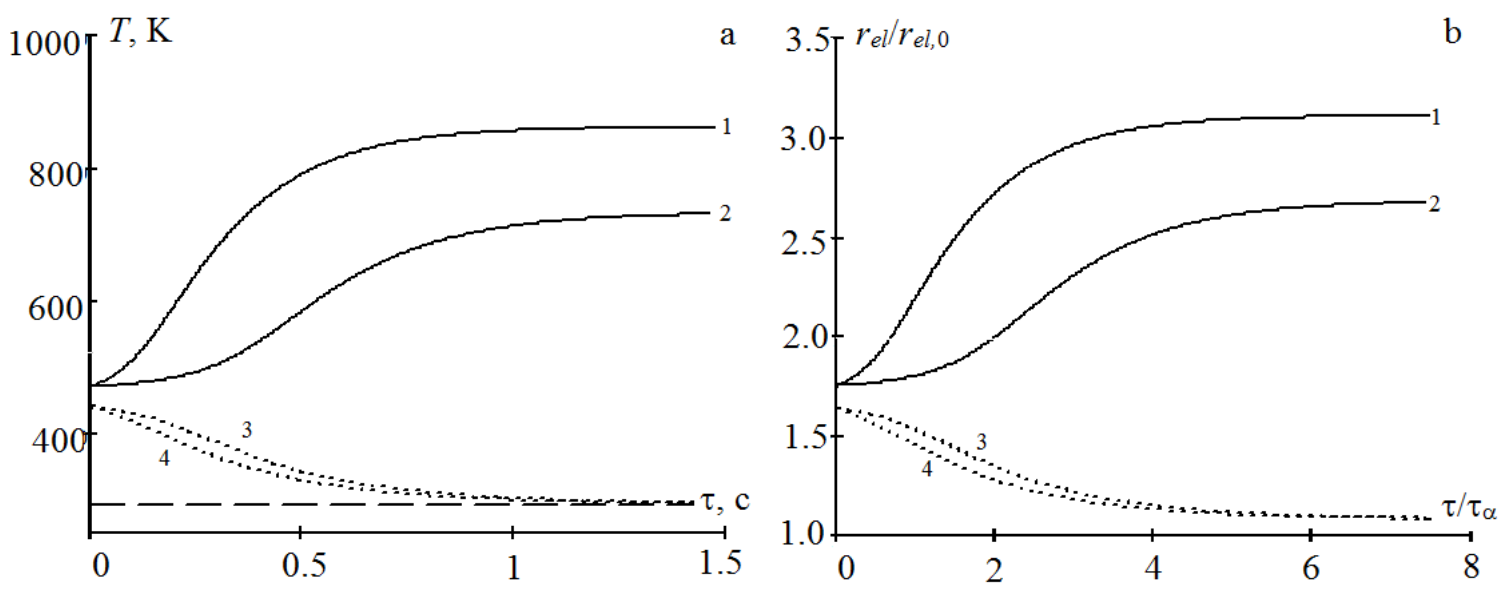

Fig. 2.Time dependences a) catalyst wire filament temperature with time b) relative resistance of $100 \mu \mathrm{m}$ diameter wire in gaseous mixture with $293 \mathrm{~K}$ temperature with hydrogen admixtures: 1) $Y_{a}=0.19 \%$, 2) $Y_{a}=0.15 \%$, 3) $Y_{a}=0.19 \%$ and $0.15 \%$. Initial filament temperature: $T_{b 1}=T_{b 2}=470 \mathrm{~K}, T_{b 3}=440 \mathrm{~K}$.

$$
\text { Characteristic time: } \tau_{a}=c_{c} \rho_{c} d /\left(4 \beta c_{p g} \rho_{g} L e^{-1+m}\right) \text {. }
$$


The implementation of forced catalytic ignition is illustrated in Fig. 2. Catalytic combustion is possible when the initial temperature of the filament is higher than the critical value. Please note that increasing the combustible gas's concentration several times has little effect on the critical value of the filament's initial temperature and resistance (Fig. 2). This is due to the fact that the catalytic ignition takes place mainly in the kinetic mode of the catalytic reaction, according to which the critical ignition temperature is a weak function of the concentration of the combustible gas impurity.

Preheating of a filament to achieve required temperature is possible applying impulse, induced or laser preheating techniques.

\section{Self-sustaining catalytic combustion}

In Fig.1, curve 2 corresponds to the case self- sustaining catalytic combustion of hydrogen impurities. Thus, for a cold mixture with a temperature of $T_{g}=293 \mathrm{~K}$ and a given hydrogen concentration, there is a stable state of catalytic combustion.

The lowest concentration of combustible gas $Y_{a e}$, at which self-sustaining catalytic combustion will still be observed, corresponds to equality of gas mixture temperature and the extrema's temperature $T_{g e}$ on a function $T_{g}(T)$. This temperature corresponds to the minimum temperature of self-supporting catalytic combustion.

The critical values of the concentration $Y_{a i, e}$ and gasair mixture's temperature $T_{g i, e}$ can be obtained $[8,9]$ from the condition of extrema on the dependences $T_{g}(T)$ (at constants $d, Y_{a}, S h$ ) or $Y_{a}(T)$ (at constants $d, T_{g}, S h$ ) and present in parametric form:

$$
\left\{\begin{array}{l}
\left.Y_{a}\right|_{i, e}=\frac{c_{p, g} R T^{2}}{Q_{a} L e^{1-m} E} \frac{S h \cdot D_{a} \cdot \rho_{g}}{d \cdot k_{0} \cdot \rho_{g s}} \exp \left(\frac{E}{R T}\right) \cdot(1+S e)^{2} \frac{\left(1-B_{T}\right)}{\left(1+\psi_{T}\right)}, \\
\left.T_{g}\right|_{i, e}=T-\frac{R T^{2}}{E}(1+S e)\left(1-B_{T}\right) .
\end{array}\right.
$$

where $B_{T}=\frac{\psi_{T}}{1+\psi_{T}} \frac{T_{0}}{T}-$ thermal diffusion correction.

The required critical point's parameters of catalytic extinction are mainly characterized by the condition $\mathrm{Se}>$ 1. From equation (6b) we find the critical values of the diffusion-kinetic ratio and the diameter of the wire:

$$
S e_{e}=\frac{\left(T-T_{g}\right) E}{R T^{2}\left(1-B_{T}\right)}-1,
$$

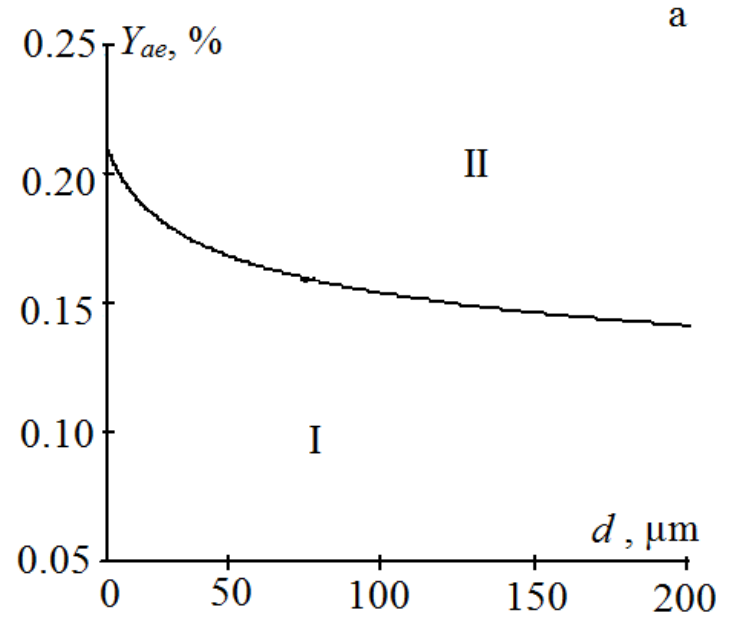

$$
d_{e}=\frac{D_{g} S h \rho_{g}}{k \rho_{g s}}\left(\frac{\left(T-T_{g}\right) E}{R T^{2}\left(1-B_{T}\right)}-1\right)
$$

Substituting (7) into expression (6a), we have the equation for obtaining the critical extinction concentration $Y_{a e}(T)$ :

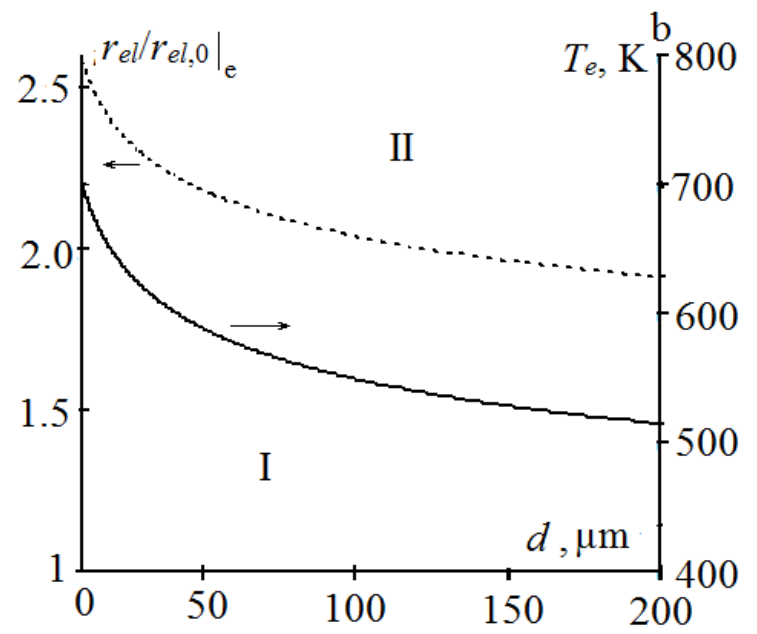

Fig. 3. Dependence a) critical quenching concentration $Y_{a, e}(a)$, b) relative resistance and critical extinction temperature, more than which there is a stable flameless combustion when the electric heating is switched off, on the platinum wire's diameter in cold hydrogen-air mixture $(293 \mathrm{~K}), \mathrm{I}$ - the absence of self-supporting catalytic combustion, II - the area of stable flameless catalytic combustion. 


$$
Y_{a e}=\frac{c_{p, g} R T^{2}}{Q_{a} L e^{1-m} E} \cdot \frac{\left(\frac{\left(T-T_{g}\right) E}{R T^{2}}\right)^{2}}{\frac{\left(T-T_{g}\right) E}{R T^{2}}-\left(1-B_{T}\right)} \frac{1}{\left(1+\psi_{T}\right)},
$$

Equations (8) and (9) constitute a system of parametric equations (parameter - catalyst temperature). For a given gas-air mixture temperature with an hydrogen admixture $\left(T_{g}=293 \mathrm{~K}\right.$ and $\left.S h=0.51\right)$, the its system's solution is presented in Fig. 3. System's solution of parametric equations (4) and (8) is presented in Fig. 3b.

The obtained dependences are divided into two regions: the region of self-supporting catalytic combustion of gases (II) and its absence (I) in a cold gasair mixture.

It is seen that the increase in the platinum wire's diameter in a practically important range of values leads to a significant decrease $Y_{a e}$ and, as a consequence, the catalytic combustion's limiting temperature $T_{e}$ and the catalyst wire's resistance (Fig. 3b). Thus, for the platinum wire $\mathrm{d}=0.1 \mathrm{~mm}$ we have the value of hydrogen concentration $Y_{a e}=0.104 \%$, which corresponds to the volume part of hydrogen $1.51 \%$.

\section{Conclusions}

These analytic relations between stationery resistance of a catalyst platinum filament and air/gas mixture temperature and hydrogen admixture ratio representing hysteretic nature are obtained for the first time. They may be applied in experimental researches of thermal and kinetic characteristics of catalytic combustion of air/hydrogen mixtures.

The dependence of combustible gas concentration on the catalyst wire's size is proposed, which allows to predict the lower limit of self-sustaining catalytic combustion in the cold gas-air mixture. It is shown that the realization this mode is possible as a result of catalytic forced ignition by pulse preheating of wire above the ignition temperature. The advantage is the low heat consumption for heating the catalyst at the initial stage.

Similar results with platinum group filaments (fines) application may be achieved reviewing results of oxidation and catalytic combustion of carbon monoxide, hydrocarbons (methane, benzene, propane, butane) with correctly selected macro kinetic conditions.

Kalinchak $\boldsymbol{V} . \boldsymbol{V}$. -Ph.D., Professor of the Department of General Physics and Physics of Thermal Power and Chemical Processes;

Chernenko O.S. -Ph.D., Associate Professor of General Physics and Physics of Thermal Power and Chemical Processes;

Fedorenko A. . - Postgraduate student of the Department of General Physics and Physics of Thermal Power and Chemical Processes.

[1] S.P.Preez, D.R.Jones, D.G.Bessarabov, A.Falch, Quaresma C. Mota das Neves, C.W. Dunnill, International Journal of Hydrogen Energy 44(49), 27094 (2019) (https://doi.org/10.1016/j.ijhydene.2019.08.168).

[2] Ying Ma, Min Chen, Cui Song, Xiaoming Zheng, Acta Physico-Chimica Sinica 24(7), 1132 (2008) (https://doi.org/10.1016/S1872-1508(08)60047-9).

[3] P.Brussino, M.S.Gross, E.D.Banús, M.A. Ulla, Chemical Engineering and Processing - Process Intensification 146, 107686 (2019) (https://doi.org/10.1016/j.cep.2019.107686).

[4] C.Trevino, F.J. Higuera and A.Linan, Proceedings of the Combustion Institute 29, 981 (2002). (https://doi.org/10.1016/S1540-7489(02)80124-9).

[5] Mitu Maria, Razus Domnina, Oancea Dumitru, Revista de Chimie (Bucharest) 69(4), 870 (2018) (https://doi.org/10.37358/RC.18.4.6218).

[6] Liqun Wu, Ting Zhang, Hongcheng Wang, Chengxin Tang and Linan Zhang, Micromachines 10(1), 71 (2019) (https://doi.org/10.3390/mi10010071).

[7] D.A. Frank-Kamenetski, Diffusion and Heat Transfer in Chemical Kinetics (Nauka, Moscow, 1987).

[8] V.V.Kalinchak, A.S. Chernenko, A.N. Sofronkov, A.V. Fedorenko, Physics and chemistry of solid state 18(1), 52 (2017) (https://doi.org/10.15330/pcss.18.1.52-57).

[9] V.V. Kalinchak, A.S. Chernenko and V.V. Kalugin, Journal of Engineering Physics and Thermophysics 87(2), 325 (2014) (https://doi.org/10.1007/s10891-015-1244-0).

[10] R.M. Soubaihi, K.M. Saoud and J. Dutta, Catalysts 8(12), 660 (2018) (https://doi.org/10.3390/catal8120660).

[11] A. Abedi, R. Hayes, M. Votsmeier and W.S. Epling, Catal Lett. 142, 930 (2012) (https://doi.org/10.1007/s10562-012-0861-x).

[12] V.V.Kalinchak, A.S. Chernenko,A.N.Sofronkov, A.V. Fedorenko, Physics and chemistry of solid state 18(4), 449 (2017) (https://doi.org/10.15330/pcss.18.4.449-454). 


\title{
В.В. Калінчак, О.С. Черненко, А.В. Федоренко \\ Гістерезис електричного опору платинової нитки в холодних воднево-повітряних сумішах
}

\author{
Одеський національний університет імені I.I. Мечникова, Одеса, Украӥна, tерlophys@опи.еdи.иа
}

Займання газоподібних горючих сумішей на каталітично активних гарячих твердих поверхнях має численні застосування в багатьох промислових процесах і являє собою складний процес, що має на увазі тісну взаємодію між поверхневими процесами і процесами перенесення в газовій суміші. У даній роботі розглядаються стійкі і критичні стани каталітичного окислення домішки водню в повітрі на платиновій нитці. Показано, що температура нитки та іï опір в залежності від температури навколишньої суміші i концентрації водню мають гістерезисний характер. Усередині даної гістерезисної області можливе досягнення режиму каталітичного горіння водню в результаті попереднього нагрівання нитки каталізатора вище певного критичного значення. Отримана залежність граничної концентрації водню від діаметра нитки каталізатора, вище якої спостерігається в холодній газовій суміші самопідтримується каталітичне горіння без протікання електричного струму.

Ключові слова: гістерезис, платинова дріт, каталізатор, вимушене займання, самопідтримуюче горіння, холодна водень-повітряна суміш. 